\title{
Tanneries: from Waste to Sustainability
}

\author{
Marcelo Farenzena ${ }^{1}$, Luciane da Silveira Ferreira ${ }^{2}$, Jorge Otávio Trierweiler $^{2 *}$, and Patrice \\ Monteiro de Aquim ${ }^{3}$ \\ ${ }^{1}$ Trisolutions; Engineering Solutions; Rua General Bento Martins, 24, sala 11001; 90010-460; Porto Alegre - RS - \\ Brasil. ${ }^{2}$ Departamento de Engenharia Química; Escola de Engenharia; Universidade Federal do Rio Grande do Sul \\ - UFRGS; R. Luiz Englert s/n.; luciane@enq.ufrgs.br; jorge@enq.ufrgs.br; 90040-040; Porto Alegre - RS - Brasil. \\ ${ }^{3}$ Laboratory of Studies in Leather and Environment (LALEATHER); Chemical Engineering Department; Federal \\ University of Rio Grande do Sul (UFRGS); Porto Alegre - RS - Brasil
}

\begin{abstract}
The aim of this work was to look for an efficient and environmentally safe solution for the leather tanning industry through a problem of non-linear programming. The results were promising and showed a significant potential of wastewater reduction. Reuse of internal streams reduced around $70 \%$ wastewater. The solutions obtained could reduce significantly the amount of chemicals and consequently the amount of waste to be treated.
\end{abstract}

Key words: Water reuse, massic integration, wastewater reduction, superstructure, tanneries

\section{INTRODUCTION}

Tanneries are industries that consume huge amount of water in several stages, generating an enormous sum of liquid effluents; which, in turn, demands significant investments and operational costs in its treatment to fit in the standards of emission normally demanded by the environmental legislation.

On average, 30,000L of water are used per ton of salty skins which, after process, generate $250 \mathrm{~kg}$ of tanned leather. In other words, the average proportion of water salty skins and produced leather is respectively 108:4:1. Transposing these numbers for a world-wide scale, the water consumption becomes enormous. To have an idea, the world-wide annual production of bovine skins is of 5,3 million tons in humid salty weight (Buljan, 1995), what corresponds to a equivalent water consumption enough to fill
530,000 semi-olympics swimming pools $(25 \mathrm{~m} \mathrm{x}$ $10 \mathrm{~m} \times 1.2 \mathrm{~m})$. This volume of water represents the drinking water consumption of the city of São Paulo during approximately 80 days. As Brazil withholds about $12 \%$ of the world-wide leather production, water consumption in the Brazilian tanneries would approximately supply the city of São Paulo per 10 days. Along with the high water consumption, also considerable amounts of chemicals (almost in the 1:1 relation w/w for amount of produced skins) are used. These substances can be recovered and its sum can be considerably reduced if techniques of recycle, reuse and regeneration are applied.

\footnotetext{
- In accordance with given preliminary of the demographic census of 2000 , carried through the Brazilian Institute of Geography and Statistic (IBGE), there are, in the city of São Paulo, 10.405.867 inhabitants, who consume daily around 2 billion liters of drinking water.
}

\footnotetext{
${ }^{*}$ Author for correspondence
} 
Reuse and recycle involve the reuse of already processed streams, enriched with pollutants. Typically, separation technologies (called in this work regeneration) are the key elements in systems with recycle/reuse to recover materials of value as solvent, metals, inorganic species and water.

The paper is organized as follows:

- initially the optimization problem will be constructed and the superstructure defined;

- later, the process of leather tanning will be briefly described;

- subsequently, the optimization problem will be solved, applying only reuse among streams, that is, the stream that leaves one process is reused in another one, that not he himself, without regeneration among streams.

\section{PROCESS INTEGRATION}

Integration of processes is a holistic methodology used in project, modifications and improvements of already existing processes and operations, to improve the exploitation of mass and energy, with emphasis in the process units.

For each pollutant will have sources, i.e. streams that carry the species; and consumers i.e. units that can accept the species. A consumer can be a reactor, heater, cooler, treatment station, discharge of residue etc. Streams that leave the consumers become sources. Thus, consumers are also generating the appointed species. Generally, the sources are prepared to be used in the consumers, which present restrictions in the concentration of the species, through segregation and separation.

An effective pollution prevention can be reached through the combination of segregation, mixes, regeneration, recycle and reuse of streams. More details on integration of processes can be found in Wang and Smith (1994), El-Halwagi (1997) and Fontana (2002).

\section{Superstructure Synthesis}

The construction of the superstructure must contemplate all the possible units and connections among the units that are candidates to an optimum project. Fig. 1 shows a schematic representation of the superstructure containing all the possible alternatives, considering only the reuse of chains.

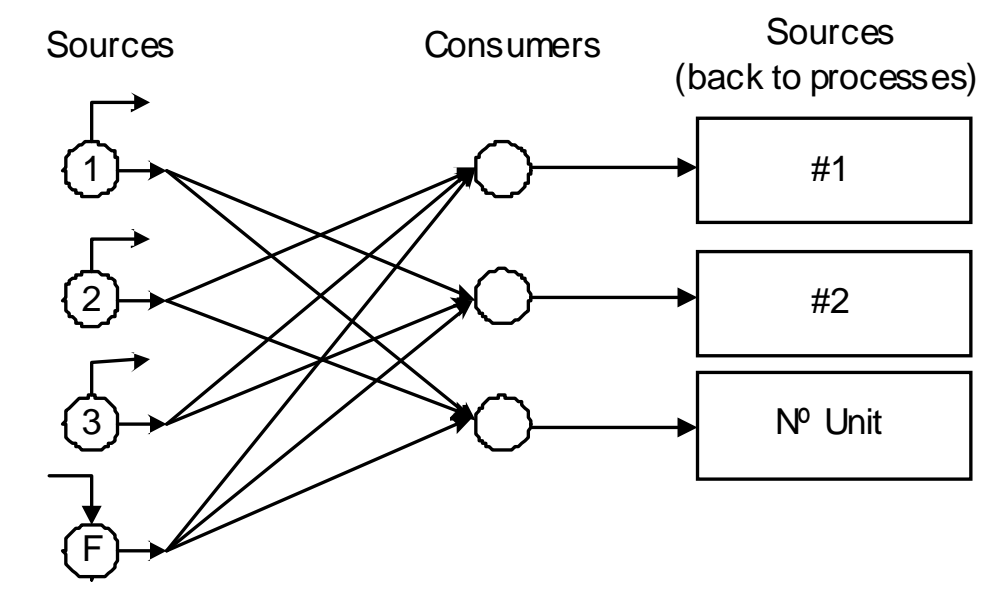

Fresh Water

Figure 1 - Schematic representation of superstructure.

\section{NLP Formulation}

Balance mass equations used in problems of water recovery, present non-linearities of bilinear type (for example, flow vs. composition). In this way, with the objective to minimize the water demand, the natural formulation of these problems is of NLP (Non-linear Programming) type. With the primordial objective to reduce the water consumption in systems containing "NoC" units that make use of water, "NoR" regenerative units of pollutants and "NoP" types of pollutants contained in the effluent, traditionally it is proposed the following formulation: 
(1)

$$
\min F=\sum_{i \in\{C\}} F_{i}
$$

subjected to the following restrictions:

a) Global Mass Balance:

$$
\sum_{i \in\{C\}} F_{i}=\sum_{i=1}^{N o U} W_{i}-\left(\sum_{i \in\{C\}} \sum_{j=1}^{N o P} \dot{M}_{i, j}-\sum_{i \in\{R\}} \sum_{j=1}^{N o P} S M_{i, j}\right)
$$

where:

$F$, mass flow rate of fresh water;

$W$, mass flow rate of wastewater;

$M$, load or mass flow rate of pollutant that enters in the processes;

$S M$, load or mass flow rate that is removed by the regenerators;

$\mathrm{NoU}$, total number of units $(\mathrm{NoU}=\mathrm{NoR}+\mathrm{NoC})$;

$\{C\}$, set of the units that use water;

$\{R\}$, set of regenerators.

b) Mass balance in each unit:

$$
\sum_{j=1}^{N o P} S M_{i, j}+\text { Lout }_{i}=\sum_{j=1}^{N o P} \dot{M}_{i, j}+\operatorname{Lin}_{i}
$$

with:

$$
\begin{gathered}
S M_{i, j}=0, \text { to } \mathrm{i} \in\{\mathrm{C}\} \text { and } \mathrm{j}=1, \ldots, \mathrm{NoP}, \\
\dot{M}_{i, j}=0, \text { to } \mathrm{i} \in\{\mathrm{R}\} \text { and } \mathrm{j}=1, \ldots, \mathrm{NoP}
\end{gathered}
$$

where:

$L_{\text {in }}$, inlet mass flow rate;

$L_{\text {out }}$, outlet mass flow rate.

c) Mass balance around the streams mixer:

$$
F_{k}+\sum_{i \neq k}^{N o U} L_{k, i}=\operatorname{Lin}_{k}
$$

Where $L_{k, i}$ is the mass flow rate of recycle/reuse that flows from unit $i$ and goes to unit $k$.

d) Mass balance around each node of stream division:

$$
W_{k}+\sum_{i \neq k}^{N o U} L_{i, k}=\text { Lout }_{k}
$$

where $L_{i, k}$ is the mass flow rate of recycle/reuse that flows from unit $k$ and goes to unit $i$.

e) Component mass balance around each node of stream mixing:

$$
X F_{j} \cdot F_{k}+\sum_{i \neq k}^{N o U} \operatorname{Xout}_{i, j} \cdot L_{k, i}=\operatorname{Xin}_{k, j} \cdot \operatorname{Lin}_{k}
$$

where:

$X F$, mass fraction of pollutant in freshwater;

$X_{i n}$, mass fraction of pollutant in the entrance of the units;

$X_{\text {out }}$, mass fraction of pollutant in the exit of the units.

f) Component mass balance around each unit:

$$
S M_{i, j}+\text { Xout }_{i, j} \cdot \text { Lout }_{i}=\dot{M}_{i, j}+\operatorname{Xin}_{i, j} \cdot \operatorname{Lin}_{i}
$$

g) Restrictions in each unit that make use of water:

$$
\begin{aligned}
& \operatorname{Xin}_{i, j} \leq \operatorname{Xin}_{i, j}{ }^{\text {maxx }} \text {, to } i \in\{C\} \text { and } j=1, \ldots, N o P \text { e } \\
& \operatorname{Lsup}_{i}=\operatorname{Lin}_{i} \text {, to } i \in\{C\}
\end{aligned}
$$

The hypotheses of the model are the following:

$>$ all the makeup water leaves the system in the form of liquid effluent;

$>$ only the processes admit fresh water;

$>$ the involved species do not interact among themselves.

The search for minimum water consumption derives from the fact to take in account economic criteria, therefore how much lesser the water demand in the system, minor will be the operational cost. Besides, minimizing the water consumption, the amount of wastewater to be treated and discarded is lesser, causing a little impact upon the environment. 


\section{TANNING PROCESS}

The process that preserves the animal skin from rottenness is called tanning. The stages of the tanning are described below.

\section{Beam House}

The beam house processes aim to prepare the skin for tanning.

Pre-Soaking: In the process of pre-soaking the skin is kept submerged in fresh water, without the addition of chemical products. This operation aims to remove the salt that recovers the skin and to restitute part of the water lost during the conservation.

Soaking: This stage moistens the skin and clean from excrements, blood, proteins and soluble carbohydrates.

Washing after soaking: It is destined to remove the chemicals in excess and replacement of the water of the skin.

Liming: In this stage, coats and dermic system are removed and the skin is swelled in order to facilitate its division.

Deliming: This process removes from the skin deposited or chemically combined alkaline substances.

Bating: The objective is unswelling of the skins, and remove the remaining coat and fat. Moreover, the skin becomes more permeable to air and water. Later, the leather is washed three times, aiming to remove organic substances and chemicals, mainly salt in excess in the leather. Here these processes will be called Washing 1, 2 and 3 .

Pickling: It has for objective to permeate collagen fibers to facilitate the penetration of the tanning agents.

\section{Tanning}

In this process the stabilization of collagen, reducing its capacity of swelling occurs. The tanning of the leather can be made using organic or inorganic products.

\section{Wet Finishing}

Wet Finishing is done to achieve certain characteristics that are not obtained during tanning.

Washing: In this stage the removal of solid residues originating from shaving (dust, scraps etc.) occurs.

Retanning with trivalent chromium: To increase the efficiency of tanning, a new batch of trivalent chromium is added.

Neutralization: To dry the leather it is necessary that it has been previously neutralized in order to prevent problems of corrosion of metals and coetaneous irritations of the operators.

Retanning: can be done with chromium or vegetable tanning agents.

Dyeing: This confers a certain coloration to the skin.

Then, the leather goes to the final finishing for industrial applications. In these processes, leather is dried, softened and eventually printed. These processes will not be inserted in this study because the amount of used water is very small.

\section{Water Consumption}

Based on the mass balance presented in Ludvik (2000), the average water consumption for the tanning of $1000 \mathrm{~kg}$ of skin is shown in Table 1 .

\section{Constraints in inlet and outlet streams}

This section determines the contaminant mass to be removed in each stream, as well as the accepted quality of contaminants in the entrance of each process. The main contaminant in beam house processes is salt. After liming, organic material is main contaminant. After the tanning, the main residue is trivalent chromium.

Table 2 shows the amount, expressed in $\mathrm{kg}$, of the pollutants removed in each one of the mentioned processes. The acceptable limits were determined from the amounts normally used in each one of the stages of the process. 
RESOLUTION OF OPTIMIZATION PROBLEM

The minimization of the water use is a problem of NLP type. For its resolution, software GAMS 2.0.23.10 was used. The minimization of water use is theoretically possible for the set of processes that have in common the same pollutant. The solution for each one of the cases will be presented.

Table 1 - Water used for tanning of $1000 \mathrm{~kg}$ of salty skins.

\begin{tabular}{l|r|r}
\hline $\mathbf{n}^{\mathbf{0}}$ & Process & Water $\mathbf{K g})$ \\
\hline 1 & Pre-soaking & 1900 \\
2 & Soaking & 1622 \\
3 & Washing after Soaking & 4605 \\
4 & Liming & 1822 \\
5 & Deliming & 3984 \\
6 & Bating & 330 \\
7 & Washing 1 & 2484 \\
8 & Washing 2 & 2484 \\
9 & Washing 3 & 2484 \\
10 & Bating & 828 \\
11 & Tanning & 1530 \\
12 & Washing after Shaving & 1200 \\
13 & Retanning with chromium & 600 \\
14 & Neutralization & 602 \\
15 & Retanning & 301 \\
16 & Dyeing & 634 \\
& TOTAL & $\mathbf{2 7 4 1 0}$ \\
\hline
\end{tabular}

Table 2 - Maximum concentration $\left(\mathrm{kg} / \mathrm{m}^{3}\right)$ of contaminant allowed in each process.

\begin{tabular}{l|r|c|r|r|r|r}
\hline \multirow{2}{*}{ Stream } & \multicolumn{3}{c|}{ Inlet Streams } & \multicolumn{3}{c}{ Outlet Streams } \\
\cline { 2 - 7 } & Salt & $\begin{array}{c}\text { Organic } \\
\text { Material }\end{array}$ & Chromium & Salt & $\begin{array}{c}\text { Organic } \\
\text { Material }\end{array}$ & Chromium \\
\hline Pre-soaking & 80 & 1 & 0 & 105 & 5,7 & 0 \\
Soaking & 20 & 1 & 0 & 85 & 6,5 & 0 \\
Washing after Soaking & 5 & 0,3 & 0 & 15 & 2,3 & 0 \\
Deliming & 0 & 0,5 & 0 & 6 & 2,7 & 0 \\
Bating & 0 & 2 & 0 & 0 & 12 & 0 \\
Washing 1 & 0 & 2 & 0 & 0 & 5 & 0 \\
Washing 2 & 0 & 1,5 & 0 & 0 & 3 & 0 \\
Washing 3 & 0 & 0,5 & 0 & 0 & 1 & 0 \\
Pickling & 0 & 0,3 & 0 & 0 & 1,8 & 0 \\
Tanning & 0 & 0 & 3 & 0 & 1 & 8 \\
Washing after Shaving & 0 & 0 & 0,1 & 0 & 1 & 0,5 \\
Retanning with chromium & 0 & 0 & 1 & 0 & 1 & 3,4 \\
Retanning & 0 & 0 & 0 & 0 & 1 & 0,3 \\
\hline
\end{tabular}

\section{Process where salt is the main contaminant}

The first set to be integrated is the one that presents salt (sodium chloride and ammonium sulphate) as the main contaminant. The related processes are: Pre-soaking, Soaking, Washing after soaking and deliming. For the concentration limits presented in Table 2, the optimization problem is decided, resulting in the superstructure showed in Fig. 2. 
Table 3 shows the flow in $\mathrm{m}^{3} / \mathrm{batch}$ of streams shown in the superstructure. The dividers are represented by letter $s$ and the respective number, as well the mixers are represented by letter $\mathrm{m}$. The fresh water is represented by FW. As the result of streams integration, it was possible to reduce $71.3 \%$ the amount of water used in the process: from $12.1 \mathrm{~m} 3 /$ batch in the original process to 3.47 $\mathrm{m} 3 / \mathrm{batch}$ in the integrated process.
Process where organic material is the main contaminant

After deliming and before tanning, the processes have the organic substance as the main pollutant: Bating, Washing 1, Washing 2, Washing 3 and Pickling. Fig. 3 shows the superstructure for the present problem of minimization and Table 4 shows the amounts $\left(\mathrm{m}^{3} / \mathrm{batch}\right)$ of water changed among the processes and freshwater.

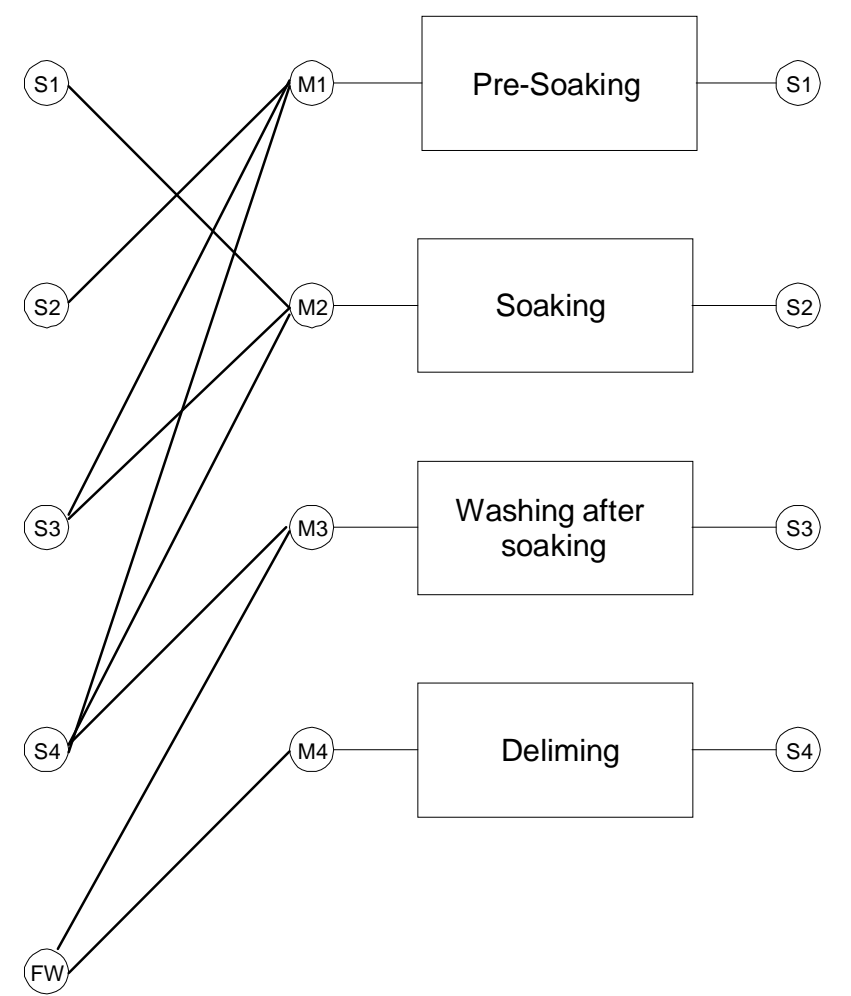

Figure 2 - Result obtained from the superstructure optimization of the processes whose contaminant is the salt.

Table 3 - Flow ( $\mathrm{m}^{3} /$ batch) among processes whose main contaminant is salt.

\begin{tabular}{lr|r|r|r|r}
\hline & Pre-soaking & Soaking & Washing after Soaking & Deliming & FW \\
\hline Pre-soaking & - & 0,472 & 0,477 & 0,868 & 0 \\
Soaking & 0,542 & - & 0,076 & 0,649 & 0 \\
Washing after Soaking & 0 & 0 & - & 1,65 & 0,33 \\
Deliming & 0 & 0 & 0 & - & 3,15 \\
\hline
\end{tabular}

The integrated process used only $2.82 \mathrm{~m}^{3} /$ batch of water, resulting in a economy of $67.2 \%$ in relation to the total used in the original process (8.61 $\mathrm{m}^{3} /$ batch).
Processes where chromium is the main contaminant

In the subsequent processes to the pickling (Tanning, Washing after Shaving, Wet Finishing and Retanning with chromium) chromium is the main contaminant in wastewater. Based on 
inherent limitations of each process, the superstructure shown in Fig. 4 was obtained. Table 5 shows the amounts of water changed among the processes and the new fresh water. From the integration of the process, it was possible to reduce $66.9 \%$ of the water consumption:

From $3.63 \mathrm{~m}^{3} /$ batch in the original process to 1.2 $\mathrm{m}^{3} /$ batch in the integrated process. process. An enormous reduction in the amount of water occurs, using only techniques of reuse. Even though some proposed connections were not feasible - because some "contaminants" (for example, $\mathrm{pH}$ ) were not computed in the streams the reduction potential justify its application, even if partially.

\section{Reduction in water consumption}

Table 6 compares the amount of water $\left(\mathrm{m}^{3} / \mathrm{batch}\right)$ spent in the original tanning and in the integrated

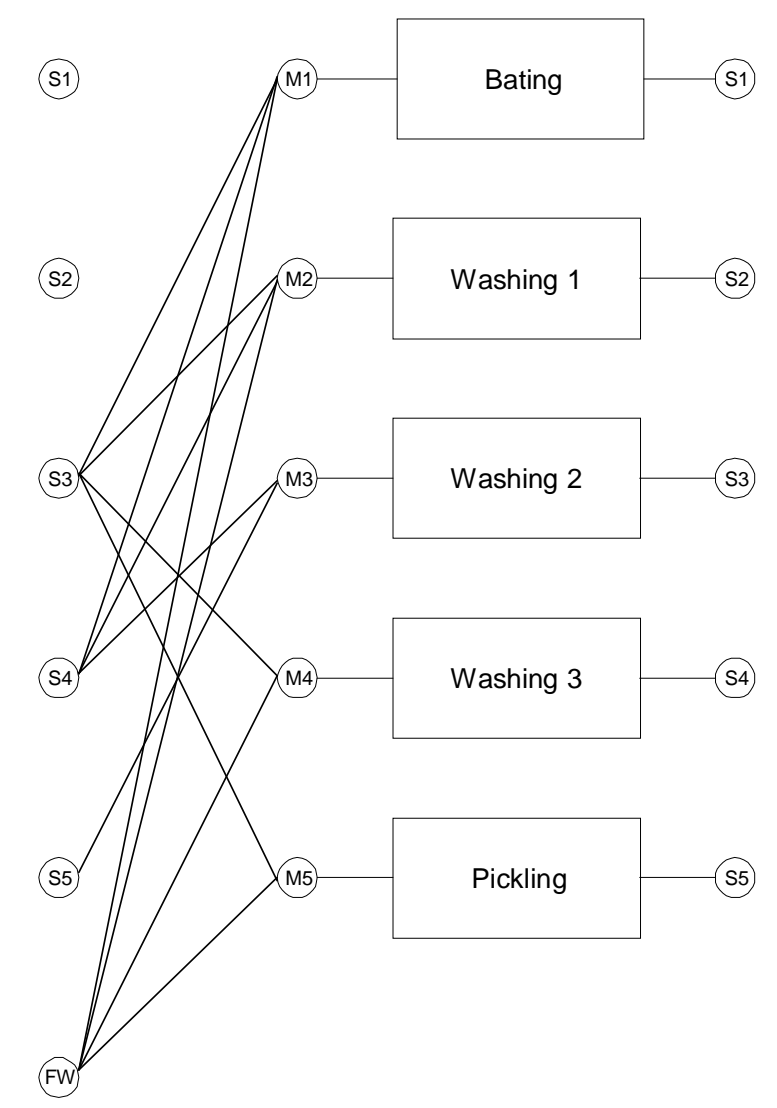

Figure 3 - Obtained structure from optimization of the superstructure for the contaminant organic substance.

Table 4 - Streams flow $\left(\mathrm{m}^{3} / \mathrm{batch}\right)$ that have the organic substance as the main contaminant.

\begin{tabular}{lccccccc}
\hline & Bating & Washing 1 & Washing 2 & Washing 3 & Pickling & \multicolumn{1}{c}{ FW } \\
\hline Bating & - & 0 & 0,165 & 0,093 & 0 & 0,036 \\
Washing 1 & 0 & - & 1,3 & 1,04 & 0 & 0,127 \\
Washing 2 & 0 & 0 & - & 1,34 & 0,655 & 0 \\
Washing 3 & 0 & 0 & 0,413 & - & 0 & 2,06 \\
Pickling & 0 & 0 & 0,065 & 0 & - & 0,59 \\
\hline
\end{tabular}




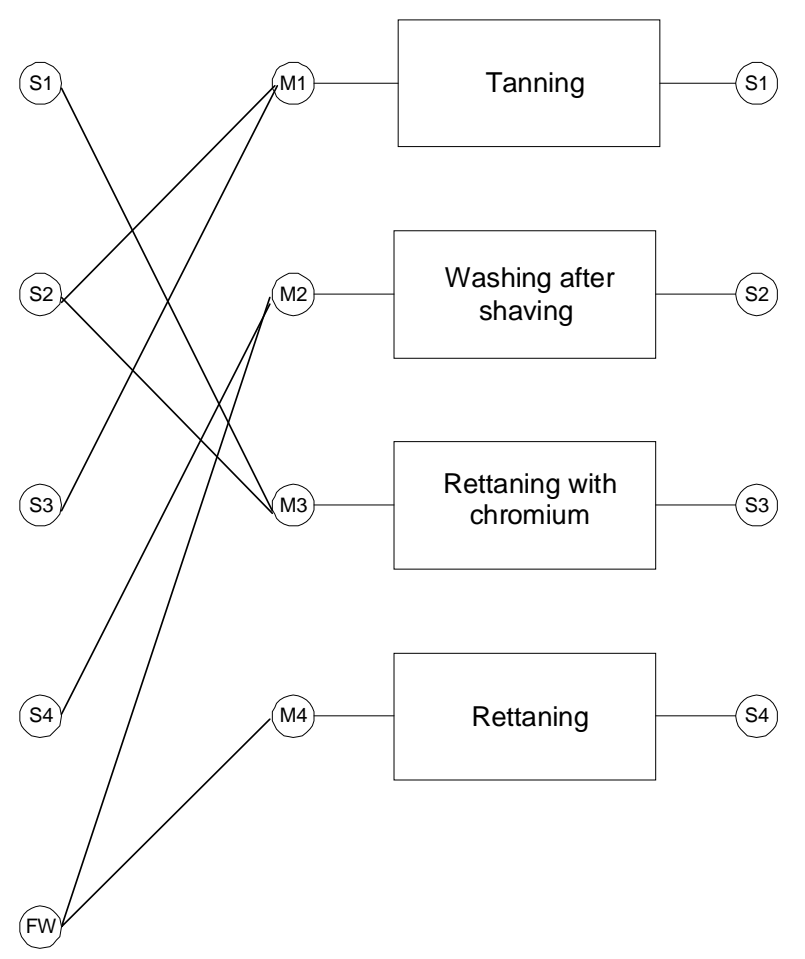

Figure 4 - Result from the optimization of the superstructure of the processes whose main contaminant is the chromium.

Table 5 - Flows (m3/batch) among the processes that have chromium as pollutant.

\begin{tabular}{lr|rrr|r|r} 
& Tanning & $\begin{array}{c}\text { Washing after } \\
\text { Shaving }\end{array}$ & $\begin{array}{c}\text { Retanning with } \\
\text { chromium }\end{array}$ & Retanning & \multicolumn{1}{c}{ FW } \\
\hline Tanning & - & 0,402 & 0,848 & 0 & 0 \\
Washing after Shaving & 0 & - & 0 & 0,872 & 0,328 \\
Retanning with chromium & 0,057 & 0,791 & - & 0 & 0 \\
Retanning & 0 & 0 & 0 & - & 0,871 \\
\hline
\end{tabular}

Table 6 - Amount $\left(\mathrm{m}^{3} / \mathrm{batch}\right)$ of water consumed in the whole process, grouped by pollutants.

\begin{tabular}{lcc|c}
\hline \multicolumn{1}{c}{ Pollutant } & Original & Integrated & Savings (\%) \\
\hline Salt & 12,1 & 3,47 & 71,3 \\
Organic Material & 8,61 & 2,82 & 67,2 \\
Chromium & 3,63 & 1,2 & 66,9 \\
TOTAL & 24,34 & 7,49 & 68,5 \\
\hline
\end{tabular}

\section{CONCLUSIONS}

The main objective of this work was the search of a more efficient and environmentally correct solution for tanneries. A series of reuse alternatives were evaluated, which were obtained through the resolution of a non-linear programming problem. The results were very promising and point to a significant potential of reduction in the water consumption. Based on streams reuse, the water consumption could be reduced significantly around $70 \%$.

The proposed solutions have a great potential to be effectively applied, since the involved costs in its implementation are low and the payback time 
high. It will be a highest advantage when the water pick up and pouring start to be taxed. Of course, to establish a specific solution for one tannery, other aspects still must be taken into account. Questions such as logistic, space for tanks of water storage installation, installation and maintenance of regenerators, automation of the feeding system and water withdrawal, still need to be answered.

\section{RESUMO}

O principal objetivo deste trabalho é a busca de uma solução mais eficiente e ambientalmente correta para a indústria do curtimento do couro (curtumes). Os curtumes são indústrias altamente consumidoras de águas e enfrentam sérios problemas com a geração de efluentes. Neste artigo, avaliaram-se alternativas de reuso da água de processo, as quais foram obtidas através da resolução de um problema de programação nãolinear, visando minimizar o consumo de água em curtumes, mantendo a qualidade do produto final. Os resultados alcançados foram muito promissores e apontam para um potencial significativo de redução no consumo de água. Baseado no simples reuso de correntes, o consumo de água já pode ser reduzido significativamente, em torno de $70 \%$. A solução obtida, além de reduzir o consumo de água, diminui significativamente o consumo de reagentes químicos e consequentemente a carga de poluentes a serem tratados posteriormente.

\section{REFERENCES}

Buljan, J. (1995), Raw hide, trade and preservation. In: International Union Leather Technologists and Chemists Societies Congress, 23., Friedrichshafen. Anais... Friedrichshafen.

El-Halwagi, M. M. (1997), Pollution Prevention through Process Integration: Systematic Design Tools. San Diego : Academic Press.

Fontana, D. (2002), Recuperação de Água de Processos: Desenvolvimento de um problema padrão. Dissertação de Mestrado. Porto Alegre : UFRGS.

Ludvik, J. (2000), Chrome management in tanyard. UNIDO (United Nations Industrial Development Organization) Repor.

Wang, Y. and Smith, R. (1994), Wastewater minimization. Chem. Eng. Sci., 49, 981-1086.

Received: September 29, 2004; Revised: February 25, 2005; Accepted: March 25, 2005. 